\title{
Dimensi Sosial dalam Pelayanan Aspirasi Masyarakat Dewan Perwakilan Rakyat Daerah Jawa Barat
}

\author{
Diah Fatma Sjoraida, Rully Khairul Anwar \\ Universitas Padjadjaran, Bandung, Indonesia \\ diah.fatma@unpad.ac.id, rully.khairul@unpad.ac.id
}

\begin{abstract}
This study discusses the performance of local legislative councils in serving the distribution of community aspirations in West Java, Indonesia. This study uses a qualitative approach to get natural settings in which there are many behaviors and events that occur. This research also uses institutional theory, because it can guide researchers on institutional structures, regulations and procedures that can have a significant impact on public policy and should not be ignored in policy analysis. The study found that in order to perform their functions as elected representatives, provincial council members always provided themselves to serve the community. To that end, members of the provincial council, among others, absorb and collect the aspirations of constituents through regular working visits; accommodate and follow up on aspirations and complaints; and provide an accountable moral and political push to constituents. In terms of conditions, all services are performed in many ways that represent the people themselves. However, some people still doubt the significance of such means for the development of democratic conditions
\end{abstract}

Keyword: House of Representatives, West Java Province, Political Aspirations, Political Communication

\begin{abstract}
Abstrak
Penelitian ini membahas kinerja dewan perwakilan rakyat daerah dalam melayani penyaluran aspirasi masyarakat di Jawa Barat, Indonesia. Penelitian ini menggunakan pendekatan kualitatif untuk mendapatkan setting alamiah di mana ada banyak perilaku dan peristiwa yang terjadi. Penelitian ini juga menggali struktur, regulasi dan prosedur kelembagaan yang bisa memiliki dampak yang signifikan pada penyaluran aspirasi oleh masyarakat. Studi ini menemukan bahwa dalam rangka untuk melaksanakan fungsi mereka sebagai wakil-wakil terpilih, para anggota dewan provinsi selalu menyediakan diri mereka untuk melayani masyarakat. Dari segi dimensi sosial, semua layanan dilakukan dalam banyak cara yang merepresentasikan rakyat itu sendiri. Meski begitu, sebagian orang masih meragukan signifikansi cara-cara tersebut bagi perkembangan kondisi demokratis. Karena ketika di kantor DPRD, pihak penyalur suara rakyat hanya berhadapan dengan pihak secretariat DPRD, terutama bagian Hubungan Masyarakat dan Protokol.
\end{abstract}

Kata Kunci: Dewan Perwakilan Rakyat Daerah, Provinsi Jawa Barat, Aspirasi Politik, Komunikasi Politik

\section{A. Pendahuluan}

Desentralisasi adalah penyerahan Urusan Pemerintahan oleh Pemerintah Pusat kepada daerah otonom berdasarkan Asas Otonomi. Dekonsentrasi adalah pelimpahan sebagian Urusan Pemerintahan yang menjadi kewenangan Pemerintah Pusat kepada 
gubernur sebagai wakil Pemerintah Pusat, kepada instansi vertikal di wilayah tertentu, dan/atau kepada gubernur dan bupati/wali kota sebagai penanggung jawab urusan pemerintahan umum. Tugas Pembantuan adalah penugasan dari Pemerintah Pusat kepada daerah otonom untuk melaksanakan sebagian Urusan Pemerintahan yang menjadi kewenangan Pemerintah Pusat atau dari Pemerintah Daerah provinsi kepada Daerah kabupaten/kota untuk melaksanakan sebagian Urusan Pemerintahan yang menjadi kewenangan Daerah provinsi (Undang-Undang Nomor 23 Tahun 2014 Tentang Pemerintahan Daerah).

Dalam konteks itu, Provinsi Jawa Barat sebagai Daerah Otonom berwenang mengatur dan mengurus Urusan Pemerintahan dan kepentingan masyarakat setempat menurut prakarsa sendiri berdasarkan aspirasi masyarakat. Dengan demikian pelaksanaan urusan pemerintahan dan kepentingan masyarakat harus didasarkan pada aspirasi masyarakat. Dalam perspektif pelaksanaan sistem manajemen pemerintahan, kepentingan dan aspirasi masyarakat disampaikan dan diterima melalui mekanisme Musyawarah Perencanaan Pembangunan (Musrenbang) yang berlangsung dari tingkat desa/kelurahan, tingkat kecamatan, tingkat kabupaten/kota sampai tingkat provinsi. Dalam perspektif pelaksanaan fungsi pemerintahan daerah, penyerapan dan penyaluran kepentingan dan aspirasi masyarakat tersebut terkait dengan pelaksanaan fungsi Dewan Perwakilan Rakyat Daerah (DPRD) (Undang-Undang Nomor 23 Tahun 2014 Tentang Pemerintahan Daerah).

Dalam dimensi pelaksanaan fungsi tersebut, DPRD provinsi mempunyai fungsi: a). pembentukan perda provinsi; b). anggaran; dan c). pengawasan. Ketiga fungsi sebagaimana dimaksud dijalankan dalam kerangka representasi rakyat di daerah provinsi. Dalam rangka melaksanakan fungsi sebagaimana dimaksud, DPRD provinsi menjaring aspirasi masyarakat. Untuk itu, anggota DPRD provinsi antara lain berkewajiban menyerap dan menghimpun aspirasi konstituen melalui kunjungan kerja secara berkala; menampung dan menindaklanjuti aspirasi dan pengaduan masyarakat; dan memberikan pertanggungjawaban secara moral dan politis kepada konstituen di daerah pemilihannya. Kunjungan kerja secara berkala dilakukan oleh Anggota DPRD ke masing-masing daerah pemilihan pada waktu reses (Undang-Undang Nomor 23 Tahun 2014 Tentang Pemerintahan Daerah).

Jumlah penduduk Provinsi Jawa Barat pada tahun 2015 mencapai 46,7 juta jiwa. 
Jumlah tersebut terdiri atas penduduk laki-laki sebanyak 23,68 juta jiwa dan penduduk perempuan sebanyak 23,03 juta. Provinsi Jawa Barat merupakan provinsi terbesar di Indonesia dalam hal jumlah penduduk. Dengan luas wilayah mencapai 35.377, 76 $\mathrm{Km} 2$, Provinsi Jawa Barat terdiri atas 18 wilayah kabupaten dan 9 kota. Delapan belas daerah kabupaten dimaksud adalah Bogor, Sukabumi, Cianjur, Bandung, Garut, Tasikmalaya, Ciamis, Kuningan, Cirebon, Majalengka, Sumedang, Indramayu, Subang, Purwakarta, Karawang, Bekasi, Bandung Barat, dan Pangandaran. Sembilan daerah kota dimaksud adalah Kota Bogor, Kota Sukabumi, Kota Bandung, Kota Cirebon, Kota Bekasi, Kota Depok, Kota Cimahi, Kota Tasikmalaya, dan Kota Banjar (http://jabarprov.go.id/index.php/pages/id/75).

Dalam pelaksanaan pembangunan, tentu tidak semua orang mendapatkan apa yang diinginkannya, terutama dari segi kesejahteraannya. Oleh karena itu, seringkali ada orang-orang yang mempermasalahkan program pembangunan, terutama pemerataan (redistribusi) (Mustari, M., \& Rahman, 2010). Di sinilah DPRD harus siap menerima berbagai aspirasi dari berbagai kalangan.

\section{B. Teori dan Metode Penelitian}

Pelayanan penyaluran aspirasi konstituen oleh anggota legislatif yang terpilih merupakan pengejawantahan suatu pola keterwakilan dua pihak yang saling membutuhkan. Pada satu sisi, konstituen membutuhkan wakil yang dapat dipercaya untuk menyerap aspirasi secara utuh dan kemudian menyalurkan aspirasinya secara efektif. Dalam konteks ini, konstituen menjadi pihak yang memberi mandat kepada pihak yang menjadi wakilnya di lembaga perwakilan. Pada sisi lain, pihak yang menjadi wakil konstituen dan sekaligus menerima mandat dari konstituen, membutuhkan dukungan konstituen untuk tampil di lembaga perwakilan dan sekaligus mengaktualisasikan peran perwakilannya di lembaga perwakilan. Dengan demikian, terjalin suatu pola keterwakilan yang melembaga dalam penyelenggaraan sistem pemerintahan yang demokratis (M. T. Rahman, 2010).

Sistem perwakilan pada umumnya lebih dimanfaatkan oleh masyarakat modern. Semakin modern satu masyarakat semakin rumit pula prosedur perwakilan yang dianut. Dalam kesempatan lain juga dikemukakan oleh Heywood bahwa: "Representation differs from democracy in that, while the former acknowledges a distinction between government and the governed, the latter, at least in its clasisical 
sense, aspires to abolish this distinction and establish popular self-government." (Heywood, 2000) Dengan demikian, representasi berbeda dari demokrasi. Representasi mengakui perbedaan antara pemerintah dan yang diperintah. Sementara demokrasi, setidaknya dalam arti klasiknya, bercita-cita untuk menghapuskan perbedaan posisi itu dan membangun pemerintahan sendiri yang lebih merakyat.

Merujuk kepada teori klasik tentang akomodasi yang berkenaan dengan hubungan antara wakil dan terwakil, dikenal dengan teori mandat. Teori ini pada dasarnya berasumsi bahwa subtansi yang diwakili oleh seorang wakil terbatas pada mandat yang disampaikan oleh orang-orang yang memberikan mandat. Hal demikian mengharuskan segala tindakan, bahkan termasuk sikap dan perilaku dari wakil harus senantiasa bersesuaian dengan kehendak dari orang-orang yang memberikan mandat. Sesuai dengan perkembangan dari teori mandat ini, berkembang atas dasar asumsi tentang kualitas mandat yang menjadi dasar hubungan antara seorang wakil dengan orang-orang yang diwakilinya (Wahidin, 2007).

Sejalan dengan perubahan demografi, wilayah dan kebutuhan Negara modern maka persoalan perwakilan politik pun menjadi menarik perhatian banyak kalangan. Implikasi dari munculnya konsep perwakilan, dibutuhkan lembaga-lembaga sebagai media yang menghubungkan masyarakat dengan pemerintah. Lembaga-lembaga inilah yang mewakili kepentingan-kepentingan politik masyarakat di tingkat pemerintahan (suprastruktur politik). Pada tahap selanjutnya, lembaga perwakilan politik tersebut dikenal sebagai lembaga legislatif (Pahlevi, 2001).

Salah satu ciri yang melekat pada setiap negara yang menganut sistem pemerintahan demokrasi adalah dilaksanakannya pemerintahan perwakilan rakyat, di mana rakyat sebagai pemegang kedaulatan tertinggi mempercayakan kepada sebagian kecil dari mereka untuk memegang kendali pemerintahan. John Stuart Mill (Dahl, 1992), mengemukakan bahwa karena itu, tidak semua orang dapat berpartisipasi dalam semua urusan umum. Akibatnya, jenis yang ideal dalam suatu pemerintahan yang sempurna haruslah "pemerintahan perwakilan".

Keterlibatan rakyat dalam pembuatan keputusan yang mengikat, terefleksi dengan adanya lembaga perwakilan rakyat. Keberadaan lembaga perwakilan rakyat atau lembaga legislatif merupakan salah satu instrumen penting dalam suatu negara yang menganut paham dan ajaran demokrasi. Partisipasi rakyat yang efektif dalam proses 
pembuatan keputusan, dikatakan oleh Dahl sebagai berikut: "Sepanjang proses pembuatan keputusan yang mengikat, warga negara harus memiliki kesempatan yang cukup dan kesempatan yang sama untuk mengemukakan pilihan mereka mengenai hasil akhir. Proses pembuatan keputusan tersebut, harus mempunyai kesempatankesempatan yang cukup dan sama untuk menempatkan masalah-masalah dalam agenda dan menyertakan alasan mengapa diambil keputusan yang itu dan bukan yang lain." (Dahl, 1992)

Di samping itu, rakyatpun berkesempatan untuk mengawasi jalannya kekuasaan pemerintahan melalui wakil-wakil mereka yang duduk dalam lembaga perwakilan dan lembaga legislatif. Hal ini didasari oleh pendapat yang dikemukakan oleh Arbi Sanit, yang menjelaskan: "Peranan perwakilan Badan Legislatif pada hakikatnya berkenaan dengan masalah hubungan antar badan tersebut, terdapat anggota badan legislatif, dengan anggota masyarakat yang diwakili mereka secara individu, berdasarkan kelompok maupun secara keseluruhan. Pandangan yang melihat hubungan tersebut merupakan salah satu masalah pokok di dalam kehidupan sistem politik pada umumnya, dan di dalam proses Badan Legislatif pada khususnya." (Sanit, 1995)

Demokrasi adalah suatu sistem pemerintahan di mana mayoritas anggota dewasa masyarakat politik ikut serta atas dasar sistem perwakilan yang menjamin bahwa pemerintah akhirnya mempertanggungjawabkan tindakan-tindakannya kepada mayoritas itu (Budiardjo, 2008). Menurut Napitupulu, tata cara menjadi wakil rakyat yang modern adalah melalui pemilihan umum, karena cara ini memberikan peluang yang sama kepada setiap orang untuk menjadi wakil rakyat di pemerintahan. Melalui pemilihan umum akan terseleksi wakil rakyat yang terpercaya dan mempunyai kemampuan menjadi wakil (Napitupilu, 2007). Namun, menurut Kantaprawira, cara menjadi wakil melalui pengangkatan atau penunjukan dapat diterima sebagai upaya penyempurnaan dari kelemahan kedua sistem pemilihan umum yakni adanya distorsi opini yang meliputi diskrepansi antara kekuatan partai dalam masyarakat dengan kekuatan kelompok masyarakat dalam parlemen (Kantaprawira, 1988).

Keterwakilan politik atau political representative diartikan sebagai terwakilinya kepentingan anggota masyarakat oleh wakil-wakil mereka di dalam lembaga-lembaga dan proses politik (Pitkin, 1967). Kadar keterwakilan tersebut ditentukan oleh sistem 
perwakilan politik (Political Representation) yang berlaku di dalam masyarakat bersangkutan. Peran wakil rakyat mengandung makna bahwa ada sesuatu yang diwakili. Napitupulu menjelaskan bahwa proses keterwakilan menyangkut dua hal, yakni keterwakilan dari sisi kepentingan, dan keterwakilan dalam sisi opini (Napitupilu, 2007).

Di Indonesia asas perwakilan fungsional juga telah dikenal, di samping asas perwakilan politik. Pemilihan Umum tahun 1971 diselenggarakan dengan mengikutsertakan baik partai politik maupun golongan fungsional. Pada bagian lain menurut Rahman, konsep perwakilan tersebut adalah Konsep Perwakilan, yakni Konsep Perwakilan (representation) yang memberikan kewenangan atau kemampuan kepada seseorang atau suatu kelompok untuk bicara dan bertindak atas nama suatu kelompok yang lebih besar. Termasuk di dalamnya adalah perubahan Undang-Undang Dasar Negara Republik Indonesia Tahun 1945 (UUD 1945) (H. . Rahman, 2007).

Sejak perubahan itu, maka sistem perwakilan dan parlemen di Indonesia berubah dari sistem unikameral menjadi sistem bikameral. Perubahan tersebut tidak terjadi seketika, tetapi melalui tahap pembahasan yang cukup panjang baik di masyarakat maupun di MPR RI, khususnya di Panitia Ad Hoc I. Proses perubahan di MPR RI selain memperhatikan tuntutan politik dan pandangan-pandangan yang berkembang bersama reformasi, juga melibatkan pembahasan yang bersifat akademis, dengan mempelajari sistem pemerintahan yang berlaku di negara-negara lain khususnya di negara yang menganut paham demokrasi.

Dalam Pasal 40 UU no 32 tahun 2004, disebutkan bahwa DPRD merupakan lembaga perwakilan rakyat daerah dan berkedudukan sebagai unsur penyelenggara pemerintahan daerah. Yang dimaksud dengan lembaga pemerintah daerah adalah Pemerintah Daerah dan Dewan Perwakilan Rakyat Daerah yang berada di tingkatan daerah. Sedangkan pemerintah daerah terdiri atas kepala daerah beserta perangkat daerah (Undang-Undang Nomor 23 Tahun 2014 Tentang Pemerintahan Daerah).

Salah satu unsur penting dalam gagasan desentralisasi adalah adanya keinginan yang kuat agar proses pembangunan di masa depan, benar-benar bertumpu pada kepentingan rakyat banyak, terutama yang ada di daerah-daerah. UU No. 32 Tahun 2004, disebutkan tugas, hak dan kewenangan DPRD secara formal mendapat porsi yang cukup luas. Dengan demikian, secara teoretis DRPD dapat berperan cukup luas 
ARTIKEL

dan penting dalam mengemban tugas-tugasnya sebagai wakil rakyat. Namun demikian, DPRD yang bekerja dalam lingkup suatu sistem politik untuk dapat mengutamakan atau memberikan suatu hasil yang maksimal yang berupa suatu keputusan atau kebijaksanaan yang memihak pada kepentingan rakyat maka sangat memerlukan input yang meliputi partisipasi atau aspirasi dan dukungan semua elemen masyarakat (Undang-Undang Nomor 23 Tahun 2014 Tentang Pemerintahan Daerah).

Penelitian ini menggunakan pendekatan penelitian kualitatif. Creswell mengemukakan paradigma penelitian kualitatif sebagai yang muncul dalam setting yang alamiah di mana di dalamnya ada banyak perilaku dan peristiwa kemanusiaan yang terjadi (Creswell, 2010). Tradisi penelitian ini (kualitatif) bertumpu pada penerapan pengetahuan yang tersirat (pengetahuan intuitif atau perasaan) karena seringkali nuansa dari beragam realitas hanya dapat diapresiasi dengan cara ini (Lincoln, Y., 1985). Maka dari itu, bentuk datanya tidak bisa dihitung (not quantifiable) dalam pengertian yang biasa.

Dalam upaya mendapatkan data dan informasi baik data primer maupun sekunder yang akurat terkait dengan indikator yang dikaji dalam penelitian digunakan teknik pengumpulan data melalui pengamatan, wawancara, dan dokumentasi tentang objek penelitian yang meliputi tema, kebijakan, dan penyelenggaraan pelayanan DPRD Provinsi Jawa Barat terhadap aspirasi masyarakat.

Selanjutnya, pendekatan penelitian dilakukan untuk mengungkap proses pelayanan penyaluran aspirasi konstituen oleh anggota DPRD dalam penyelenggaraan Pemerintahan Provinsi Jawa Barat. Dengan pengungkapan proses yang demikian itu, anaclisis diarahkan untuk memaknai setiap dimensi analisis. Teknik yang digunakan adalah analisis data kualitatif dari Miles dan Huberman yang terdiri dari tiga alur kegiatan yang terjadi secara bersamaan yaitu reduksi data, penyajian data, dan penarikan kesimpulan atau verifikasi (Matthew B. Miles \& Huberman, 1994)

\section{Pembahasan}


Penyelenggaraan pemerintahan daerah bertujuan mewujudkan kesejahteraan masyarakat. Pemerintahan Daerah adalah penyelenggaraan urusan pemerintahan oleh pemerintah daerah dan dewan perwakilan rakyat daerah menurut asas otonomi dan tugas pembantuan dengan prinsip otonomi seluas-luasnya dalam sistem dan prinsip Negara Kesatuan Republik Indonesia sebagaimana dimaksud dalam Undang-Undang Dasar Tahun 1945.

Salah satu ciri partisipasi politik rakyat antara lain adalah adanya input yang berbentuk aspirasi masyarakat yang secara teknis dapat dikatakan sebagai tuntutan dan dukungan. Aspirasi merupakan ungkapan ketidakpuasan atau keinginan kuat dari masyarakat yang disampaikan kepada pemerintah dalam bentuk pernyataan sikap, pendapat, kritikan, harapan, masukan dan saran (M. T. Rahman, 2010).

Masyarakat pada umumnya berhak menyampaikan aspirasinya berkaitan dengan hal-hal mengenai pembangunan, pemerintahan dan kemasyarakatan daerah. Namun, karena banyaknya aspirasi yang masuk sehingga pemerintah -termasuk DPRD—mendapatkan kesulitan dalam penyampaian untuk menanggapi aspirasiaspirasi yang disampaikan oleh masyarakat (Wawancara dengan IQ, anggota DPRD Jawa Barat, Bandung, 11/01/2018).

Dalam menyampaikan aspirasinya, masyarakat umumnya mengaspirasikan melalui demonstrasi. Demonstrasi atau unjuk rasa merupakan sebuah gerakan protes yang dilakukan sekumpulan orang di hadapan umum. Demo atau unjuk rasa biasanya dilakukan untuk menyatakan pendapat kelompok penentang kebijakan atau dapat pula dilakukan sebagai upaya penekanan secara politik dari kepentingan suatu kelompok (Wawancara dengan PP, anggota DPRD Jawa Barat, Bandung, 10/01/2018).

Bagi penguasa, demo atau unjuk rasa ini bukanlah kebiasaan baik, karena dapat mengurangi kewibawaan pemerintah di masyarakat. Terdapat dua bentuk aspirasi dilihat dari bentuk penyampaiannya, yaitu aspirasi langsung dan aspirasi tidak langsung. Aspirasi langsung merupakan bentuk aspirasi masyarakat yang disampaikan secara langsung tanpa perantara, seperti aksi unjuk rasa dimana aksi ini terkadang menjadi sangat tidak terkontrol karena tidak adanya tanggapan atau tindak lanjut yang dilakukan pemerintah dalam menyelesaikan permasalahan yang ada, seperti aksi bakar- 
ARTIKEL

membakar, merusak gedung maupun aksi-aksi lain yang merugikan banyak pihak (Wawancara dengan YU, anggota DPRD Jawa Barat, Bandung, 10/01/2018).

Sedangkan aspirasi tidak langsung merupakan bentuk aspirasi masyarakat yang disampaikan melalui media, seperti surat yang dikirimkan kepada pemerintah, email yang dikirimkan melalui website dan lain sebagainya. Kedua aspirasi ini merupakan salah satu saluran dari proses komunikasi dalam cara menyampaikan pesan ketidakpuasan terhadap suatu kebijakan publik (Sundari, Sjoraida, \& Anwar, 2017).

Dalam menangani berbagai aspirasi masyarakat, pihak DPRD Jawa Barat kini sudah mempunyai media sendiri yang dapat mengumumkan semua kegiatannya, yaitu http://dprd.jabarprov.go.id/. Di dalam portal tersebut, terdapat rubrik terbuka, yaitu “e-aspirasi”. Dengan media partisipasi masyarakat ini, DRPD pun dapat memuat proses-proses penanganan aspirasi yang melalui langkah-langkah seperti: fact-finding, planning, communication, dan evaluation (Wawancara dengan $\mathrm{NN}$, pejabat kesekretariatan DPRD Jawa Barat, Bandung, 10/01/2018).

Fact finding atau pencarian fakta ini dilakukan oleh Humas \& Protokoler Sub Bagian layanan partisipasi dalam menanggapi aspirasi peserta demo. Dalam hal ini Humas \& Protokoler Sub bagian layanan aspirasi sekretariat DPRD Provinsi Jawa Barat, mencari data dan fakta yang ada di lapangan sesuai dengan kenyataan, kemudian diolah menjadi bentuk informasi yang dibutuhkan sesuai dengan tujuan dari program yang akan dijalankan (Wawancara dengan AH, pejabat Humas DPRD Jawa Barat, Bandung, 10/01/2018).

Pada tahap ini, bagian Humas \& Protokol Sekretariat DPRD Provinsi Jawa Barat dalam memfasilitasi aspirasi peserta demo buruh melalui sub-bagian layanan aspirasi adalah berusaha mencari keterangan yang merupakan data faktual. Data tersebut diolah terlebih dahulu, sehingga memperoleh kesimpulan atas kebenaran data yang diperoleh itu (Sjoraida \& Anwar, 2017).

Dalam tahap perencanaan, bagian Humas dan Protokol Sekretariat DPRD Provinsi Jawa Barat dalam memfasilitasi partisipasi publik adalah melakukan sebuah daftar penyusunan perencanaan dari hasil data atau fakta yang diperoleh. Dalam perencanaan tersebut ada kegiatan yang dilakukan untuk menunjang keberhasilan pada saat pelaksanaan kegiatan dalam memfasilitasi partisipasi publik. Dengan adanya daftar tersebut akan dapat dilakukan pemikiran dengan cepat untuk mengatasinya 
dan nantinya perencanaan itu perlu dipikirkan dengan matang, oleh karena itu kegiatan ini merupakan salah satu tahap yang turut menentukan suksesnya pekerjaan bagian Humas keseluruhan (Wawancara dengan AH, pejabat Humas DPRD Jawa Barat, Bandung, 10/01/2018).

Perencanaan ini berisikan segala kegiatan yang akan dilaksanakan oleh Humas \& Protokoler Sub Bagian Layanan Aspirasi sekretatariat DPRD Provinsi Jawa Barat, yang masih membutuhkan penyesuaian dengan data dan fakta yang ada di lapangan, sehingga yang disusun menjadi matang dan tepat sasaran (Wawancara dengan NN, pejabat kesekretariatan DPRD Jawa Barat, Bandung, 10/01/2018).

Tahap communication yang dilakukan oleh Humas dan Protokol Sub bagian layanan aspirasi sekretariat DPRD Provinsi Jawa Barat dalam memfasilitasi aspirasi publik peserta demo adalah dengan melakukan implementasi dalam kegiatan tersebut sehingga komunikasi pun berlangsung dengan sendirinya (Wawancara dengan $\mathrm{AH}$, pejabat Humas DPRD Jawa Barat, Bandung, 10/01/2018).

Evaluasi adalah tahap terakhir setelah tahap-tahap fact finding, Planning, Communication. Tidak jarang perubahan suatu program yang telah direncanakan akan memberikan dampak yang positif atau negatif, untuk langkah selanjutnya dalam setiap tahap program harus fleksibel demi kelancaran kegiatan yang dilakukan (Wawancara dengan AI, anggota DPRD Jawa Barat, Bandung, 10/01/2018).

Dalam tahap ini, Humas \& Protokol sub bagian layanan aspirasi Sekretariat DPRD Provinsi Jawa Barat melakukan peninjauan terhadap kegiatan yang sedang berlangsung yang akan diterapkan pada saat pelaksanaan kegiatan selanjutnya (Wawancara dengan NN, pejabat kesekretariatan DPRD Jawa Barat, Bandung, 10/01/2018).

Dalam menindaklanjuti pemenuhan aspirasi masyarakat, tidak lepas dari aktivitas peranan struktur dan prosedur dalam kerangka sistem pemerintahan daerah, juga tidak lepas dari permasalahan yang dihadapi, bagaimana menampung dan mengartikulasikan aspirasi masyarakat melalui komunikasi dan koordinasi antar unit kerja agar tercipta suatu sistem pemenuhan aspirasi dalam prosedur sistem pemerintahan daerah, yang umpan baliknya dapat diketahui dan dirasakan oleh masyarakat, dan yang tidak kalah penting adalah integritas dan kemampuan anggota 
DPRD dalam memahami dan menampung keinginan dan aspirasi rakyat (Sundari et al., 2017).

Menyuarakan aspirasi kini sudah disahkan oleh UU No. 9 Tahun 1998 tentang kemerdekaan menyampaikan pendapat di muka umum, tetapi tetap harus berdasarkan peraturan atau rambu-rambu yang telah disepakati bersama (Wawancara dengan NN, pejabat kesekretariatan DPRD Jawa Barat, Bandung, 10/01/2018).

Di dalam menjalankan tugas, wewenang, hak dan kewajibannya DPRD Provinsi Jawa Barat dibantu oleh Sekretariat Humas dan Protokoler. Adapun Humas \& Protokoler ini memiliki sub-sub bagian diantaranya Sub bagian layanan aspirasi yang mempunyai tugas pokok menyelenggarakan layanan hubungan DPRD dengan masyarakat dan lembaga-lembaga kemasyarakatan serta memfasilitasi layanan aspirasi. Semua kegiatan itu didukung oleh pemberitaan dalam media, yaitu terutama oleh media DPRD Jawa Barat sendiri, yaitu http://dprd.jabarprov.go.id/ (Wawancara dengan NN, pejabat kesekretariatan DPRD Jawa Barat, Bandung, 10/01/2018).

Walaupun demikian, para anggota DPRD tidak boleh berpangku tangan begitu saja, karena mereka adalah yang menjadi 'wakil rakyat'-nya seperti yang disebutkan di atas. Oleh karena itu, mereka itulah yang harus melayani rakyat dalam menyerap aspirasi mereka. Dan tugas tersebut adalah melekat pada mereka. Sedangkan masyarakat selalu merindukan bahwa 'wakil' mereka berada beserta mereka, dalam suka maupun duka. Wakil rakyat seharusnya lebih intim secara sosial, tidak hanya setelah terpilih, mereka kemudian lupa pada para pemilihnya.

\section{Simpulan}

Berdasarkan hasil dan pembahasan penelitian dirumuskan simpulan penelitian sebagai berikut:

1. Secara konstitusional, DPRD adalah tempat menampung aspirasi sebagai bentuk partisipasi politik masyarakat.

2. Kegiatan penampungan aspirasi masyarakat di Jawa Barat dapat dilacak terutama pada media yang dibangun oleh DPRD Jawa Barat, yaitu http://dprd.jabarprov.go.id/.

3. Yang menangani media, baik di dalam maupun keluar di DPRD adalah Sekretariat Humas dan Protokoler. 
ARTIKEL

4. Dalam menjalankan tugasnya, Sekretariat Humas dan Protokoler menjalankan fungsi-fungsi fact-finding, planning, communication, dan evaluation..

\section{DAFTAR PUSTAKA}

Budiardjo, M. (2008). Dasar-Dasar Ilmu Politik. Jakarta: Ikrar Mandiriabadi.

Creswell, J. W. (2010). Research Design: Pendekatan Kualitatif, kuantitatif, dan Mixed. Yogyakarta: Pustaka Pelajar.

Dahl, R. A. (1992). Demokrasi dan Para Pengkritiknya Jiid 1. Jakarta: Yayasan Obor.

Heywood, A. (2000). Key Concepts in Politics. New York: Palgrave Macmillan.

Kantaprawira, R. (1988). Sistem Politik Baru. Bandung: Sinar Baru.

Lincoln, Y., and E. G. (1985). Naturalistic Inquiry. Newbury Park, CA: Sage Publications.

Matthew B. Miles, \& Huberman, A. M. (1994). Qualitative Data Analysis: An Expanded Sourcebook. London and New Delhi: Sage Publications, Inc.

Mustari, M., \& Rahman, M. T. (2010). Peranan Pesantren dalam Pembangunan Pendidikan Masyarakat Desa. MultiPress.

Napitupilu, P. (2007). Menuju Pemerintahan Perwakilan. Bandung: Alumni.

Pahlevi, R. M. (2001). Peran Partai Politik Indonesia. Jakarta: Gramedia.

Pitkin, H. F. (1967). The Concept of Representation. Berkeley, Los Angeles: University of California Press.

Rahman, H. . (2007). Sistem Politik Indonesia. Jakarta: Graha Ilmu.

Rahman, M. T. (2010). Social Justice in Western and Islamic Thought: A Comparative Study of John Rawl's and Sayyid Qutb's Theories of Social Justice. Universiti Malaya.

Sanit, A. (1995). Perwakilan Politik di Indonesia. Jakarta: Rajawali Press.

Sjoraida, D. F., \& Anwar, R. K. (2017). Urgensi unsur elit dalam pelaksanaan kebijakan informasi publik di jawa barat.

Sundari, I. P., Sjoraida, D. F., \& Anwar, R. K. (2017). AKUNTABILITAS PENYAMPAIAN ASPIRASI MASYARAKAT DEWAN PERWAKILAN RAKYAT DAERAH JAWA BARAT. Ilmu Politik Dan Komunikasi, 7(1), 63-70.

Wahidin, S. (2007). Dimensi Kekuasaan Indonesia. Yogyakarta: Pustaka Pelajar. 